\title{
The utilization of project risk monitoring and control practices and their relationship with pro- ject success in construction projects
}

\author{
Kennedy Christopher Obondi ${ }^{\mathrm{a}^{*}}$
}

${ }^{a}$ School of Business, Northcentral University, 11355 N. Torrey Pines Road, La Jolla, CA 92037 USA

\section{H R O N I C L E}

Article history:

Received: June 15, 2021

Received in revised format: June 30,2021

Accepted: July 22, 2021

Available online:

July 22, 2021

Keywords:

Risk management practices

Project risk control

Risk monitoring and control

Construction project management

Risk response

Project success

\section{A B S T R A C T}

\begin{abstract}
Risk monitoring and control is often poorly implemented in construction projects because of a failure to monitor and manage identified risks. Construction companies experience significant losses due to project managers' lack of project risk monitoring and control in construction projects. Most studies have concentrated on risk identification, risk assessment, and risk analysis processes while neglecting crucial risk management processes of risk control, risk monitoring, and risk response. The lack of research on these three crucial processes highlights a gap in the literature concerning how these processes can increase the delivery of successful projects. The purpose of this study was to examine whether the utilization of project risk monitoring and control practices was related to project success in construction projects in the United States. An electronic survey instrument was used to collect data from a sample of 50 construction project managers in the Dallas-Fort Worth area in the state of Texas, in the United States. Spearman rho correlation analysis was used to examine the relationship between project risk monitoring and control practices and project success. The results of this study indicated that all project risk monitoring and control practices, including risk reassessment, risk audits, contingency reserves analysis, and risk status meetings, were significantly and positively related to project success in construction projects. One of the recommendations presented in this study was that future research should conduct the same study in developing countries to see if the study's findings remain the same and generalizable. The study concluded that construction organizations should regularly consider the importance and usage of project risk monitoring and control practices and apply them to improve the success rate of a project.
\end{abstract}

\section{Introduction}

Risk monitoring and control is often poorly implemented in construction projects because of a failure to manage and monitor risks that have been identified (Chapman, 2019). A risk is an uncertain event that can negatively or positively affect project goals like cost, quality, scope, and time (Project Management Institute [PMI], 2017). Project risk monitoring and control is a process of tracking identified risks, identifying and analyzing new risks, monitoring the implementation of risk response plans, and assessing the effectiveness of risk management processes throughout a project (PMI, 2017). A risk is likely to occur during a construction project's lifecycle, resulting in reduced project performance (Obondi, 2020a). The construction industry is subject to a higher risk level than other industries because of the complex and dynamic character of construction activities. External and internal factors like project budget and schedule constraints, complexity, complicated procedures,

* Corresponding author. Tel.: +18172645853

E-mail address: kobondi@yahoo.com (K. C. Obondi) 
hostile environments, scope changes, and technical difficulties are among the primary risk sources in construction projects (Alashwal and Al-Sabahi, 2018). Construction companies often suffer significant losses because project managers do not adequately engage in risk monitoring and control in construction projects that they oversee (Obondi, 2020a). These losses can amount to up to $85 \%$ of the total cost of a project (Senesi et al., 2015). Construction project managers often use improper risk management methods when dealing with risks. Frequently, rather than following proper risk management processes, project managers utilize personal instincts for both managing and mitigating risks (Qazi et al., 2016).

Since risks impact project performance, risks must be adequately controlled, monitored, and handled to ensure successful project delivery. Unmonitored or uncontrolled risks could cause cost overruns, scheduling delays, inferior project performance, and, ultimately, project failure (Khan \& Gul, 2017). The failure of a project is harmful to the bottom-line performance, reputation of a construction organization, its share price, the confidence of stakeholders, and the achievement of an organization's strategic objectives (Chapman, 2019). Risks like accidents, design errors, poor safety records, structural and equipment failures plague the construction industry, which has resulted in reduced customer satisfaction (Khan and Gul, 2017). Additionally, the Construction Industry Institute (2014) reported that merely 5\% of projects were on budget, were completed within the correct time frame, and met quality requirements, which resulted in low construction performance. In turn, low construction performance was associated with the failure to monitor and manage risks appropriately (Chapman, 2019).

As risks in construction projects persist, so too does the necessity to embrace reasonable risk management practices. Risk monitoring and control practices should be emphasized and implemented in every construction project to ensure the achievement of project goals (Obondi, 2020a). Project managers should be aware of risk monitoring and control practices that include change control, risk audits, risk reassessment, risk status meetings, risk trend analysis, risk matrices, contingency reserves analysis, and technical performance measurement. These practices minimize the negative impacts of risk if performed regularly and adequately (Didraga, 2013; PMI, 2013; Salah \& Moselhi, 2015b).

\subsection{Rationale for the Study}

Even though many risk management aspects have been examined regarding construction projects, risk management practices are seldom applied in day-to-day project routines (Carvalho \& Rabechini, 2015; Khan \& Gul, 2017; Sharma, 2013; Zhao et al., 2013). When proper risk management practices are not used, large financial deficits in a project, which can be up to $85 \%$ of the total cost of a project, can sometimes occur (Senesi et al., 2015). Furthermore, Cakmak and Tezel (2019) found that most studies have concentrated on the identification of risk, risk assessment, and risk analysis while neglecting other crucial processes like risk control, risk monitoring, and risk response. The absence of research concentrating on these three crucial processes highlights a gap in the literature concerning how these processes can boost the delivery of successful projects.

Serpell, Ferrada, and Rubio (2017) considered the value of understanding and following risk response, monitoring, and control practices while carrying out a construction project. They argued that project managers often neglect these essential steps, which reduces performance and the likelihood of a project's success. Similarly, Sigmund and Radujkovic (2016) noted that risk response, monitoring, and control practices were often the last processes to be used when projects were managed. Indeed, project managers often tend to skip specific risk response and monitoring steps as well as control practices simply because they followed the parameters of past construction projects that had similar boundaries (Obondi, 2020a; Sigmund \& Radujkovic, 2016).

Further highlighting the gaps found in previous studies, the PMI (2011) listed the underuse of control practices, risk monitoring, and risk responses as three of the top 10 mistakes found in the construction industry. While the monitoring of risks should be a continuous process and be practiced over the lifetime of a project, many project managers often fail to engage in the practice (Obondi, 2020a). Consequently, project managers tend to be confused about risk causes, events, and impacts. They also do not consider contingency plans along with response plans, do not hold team members accountable for particular risk events, and do not make risk management an ongoing process or a priority (Obondi, 2020a; PMI, 2011). Project managers tend to pay little attention to risk control practices, leaving the risks associated with many projects often unattended and untreated (Baharuddin \& Yusof, 2017). Therefore, it appeared necessary to investigate this underexplored area of project risk management. The results of this study will help close the gap in this underexplored project risk management practice.

\subsection{Statement of the Problem}

The problem addressed in this study was that construction companies are experiencing significant losses due to the absence of project risk monitoring and control by project managers in the construction projects that they oversee. These losses can amount to up to $85 \%$ of the total cost of a project (Senesi et al., 2015). This problem persists because of the absence of risk management capabilities and knowledge; failure to respond, monitor, and control identified risks; and risks being inadequately considered by project managers (Chapman, 2019; Fabricius \& Buttgen, 2015; Serpell et al., 2017). If risks are 
inadequately monitored and controlled, a cascade of problems can ensue, including accidents, cost overruns, delays in schedules, design errors, equipment failure, labor strikes, low customer satisfaction, poor quality work, structural failure, and, ultimately, even project failure (Khan \& Gul, 2017). The failure of a project can be detrimental to bottom-line performance, reputation, share price, stakeholder confidence, and the realization of an organization's strategic objectives (Chapman, 2019). While a lack of proper project risk monitoring and control process in construction projects is known to cause project failure, what remains unknown is how implementing project risk monitoring and control practices impact the level of project success in construction projects in the United States.

\subsection{Purpose of the Study}

The purpose of this study was to examine whether the utilization of project risk monitoring and control practices (risk reassessment, risk audits, contingency reserves analysis, and risk status meetings) is related to project success in construction projects in the United States. Specifically, the main objectives of this study were to:

1. Examine whether the usage of the risk reassessment technique is related to project success in construction projects.

2. Examine whether the usage of the risk audits technique is related to project success in construction projects.

3. Examine whether the usage of contingency reserves analysis is related to project success in construction projects.

4. Examine whether the usage of risk status meetings is related to project success in construction projects.

\subsection{Research Questions}

This research addressed the following research questions (RQs):

RQ1. To what extent is the utilization of risk reassessment related to project success in construction projects?

RQ2. To what extent is the utilization of risk audits related to project success in construction projects?

RQ3. To what extent is the utilization of contingency reserves analysis related to project success in construction projects?

RQ4. To what extent is the utilization of risk status meetings related to project success in construction projects?

\subsection{Hypotheses}

The proposed hypotheses for this study are:

H10. There is no positive relationship between risk reassessment and project success in construction projects.

H1 a. There is a positive relationship between risk reassessment and project success in construction projects.

H20. There is no positive relationship between risk audits and project success in construction projects.

$\mathbf{H 2}$ a. There is a positive relationship between risk audits and project success in construction projects.

H3. There is no positive relationship between contingency reserves analysis and project success in construction projects.

H3a. There is a positive relationship between contingency reserves analysis and project success in construction projects.

H4. There is no positive relationship between risk status meetings and project success in construction projects.

H4a. There is a positive relationship between risk status meetings and project success in construction projects.

\subsection{Location of the Study}

This study was conducted in Dallas-Fort Worth, in the state of Texas, in the United States. The population of the study included construction project managers who met the following criteria: each construction project manager must (a) have been currently employed as a project manager and had a minimum of three years of experience managing construction projects, (b) had managed risk on a completed construction project, (c) must have possessed an academic or professional qualification or a bachelor's degree or higher, and (d) must have been employed in a construction company in the DallasFort Worth, Texas area.

\subsection{Significance of the Study}

This study will serve as a source of knowledge that practitioners may utilize to manage or respond to risks in their area of practice. This study provides project management practitioners with a more profound and detailed understanding of the benefits and relationships that exist between project risk monitoring and control practices and project performance. The findings from this study will help organizations solve project risk management issues to ensure the successful completion of their projects. The results from this study will help close the gap in underexplored project risk management practices. Suppose a connection exists between project success and the use of project risk monitoring and control practices. In that case, a genuine reason could exist for the increased use of these practices as a guideline for improving and enhancing the implementation of risk management in the construction industry. 


\section{Literature Review}

The objectives of risk monitoring and control practices are to monitor the project's progress and the environment, assess specific risk situations, and operate risk management mechanisms (Ning \& Mao, 2011). Suitable project risk monitoring and control practices aid managers in assessing and analyzing risks while creating appropriate risk response strategies (Ning \& Mao, 2011; PMI, 2017). Appropriate project risk monitoring and control processes also enhance the efficiency of a risk management approach throughout the project life cycle (Obondi, 2020a; PMI, 2017). The use of risk monitoring and control practices in a construction project prevents project failure and involves all relevant stakeholders in achieving a project's objectives (Grigore et al., 2018). In a construction project, everyone involved in the project must perform risk monitoring and control processes to prevent project failure (Obondi, 2020a).

In project risk monitoring and control, monitoring focuses on the status of risks and reviews the actions taken to mitigate them, while control focuses on correcting the deviations from the planned response actions to the risk and improving the processes of risk management (Mandru, 2016). Monitoring and controlling risk are critical in the construction industry. Cagliano et al. (2015) discovered that for project managers in construction projects to reduce, transfer, or avoid risks in a project, they must pass through different steps of the risk management process. They noted that the steps needed for the risk management process included risk planning, risk identification, risk analysis, risk response, and risk monitoring and control. However, project managers cannot reduce risks in construction work if they only identify and assess risks without monitoring and controlling them (Obondi, 2020a). A strong need exists for assessing, monitoring, and controlling risk throughout all phases of a project.

Risks must be proactively identified, assessed, analyzed, mitigated, monitored, and controlled throughout the life cycle of a project. Construction project managers should proactively and continuously manage, monitor, and control project risks to boost project performance and prevent project failure. Project risk monitoring and control help track risks and implement risk response plans, reducing the impact of risks on project performance (Obondi, 2020a). The regular implementation of the risk monitoring process enables a project team to define what must be improved from one analyzed period to another (Mamoghli et al., 2015).

\subsection{Project Risk Monitoring and Control Practices}

In project risk management, risk monitoring and control practices include risk reassessment, risk audits, risk trend analysis, contingency reserves analysis, risk status meetings, a risk matrix, change control, and technical performance measurement (Didraga, 2013; PMI, 2013; Salah \& Moselhi, 2015b). These practices, when performed regularly, minimize the adverse effects of risk in a project (PMI, 2013). The scope of this current research study was limited to the examination of the following four project risk monitoring and control practices: risk reassessment, risk audits, contingency reserves analysis, and risk status meetings.

\subsubsection{Risk Reassessment}

In project risk management, risk reassessment identifies new risks, reassess current risks, and closes outdated risks in a project (Project Management Institute [PMI], 2017). As a project progresses, risks are likely to occur when there are changes in the project environment, making risk reassessment a necessary and ongoing task in managing project risks (PMI, 2009). A project manager should ensure that periodic risk reassessment, including risk identification, analysis, and response planning, is repeated at reasonable intervals to respond to project risks effectively. Typical reasons for risk reassessment are the emergence of unexpected risks, the need to analyze a complex change request, the need for project phase end review, the need for project replanning, and periodic reviews to ensure the project risk information remains current (PMI, 2009).

In reassessing project risks, Diab et al. (2012) found that the usage of risk assessment boosts project and construction management practices by helping project managers to focus on significant risk drivers faced in a project. This practice could also improve cost and schedule performance through the better management of potential risks. Haji-Kazemi et al. (2013) found that project assessments could reveal issues that needed continuous monitoring. Similarly, Williams et al. (2012) observed that project assessments are necessary to evaluate project expectations and identify relevant early warning signs of project problems, project failure, underperformance, or cost overruns.

\subsubsection{Risk Audits}

Risk audit is the examination of the effectiveness of risk responses and risk management processes in dealing with risks and their root causes (PMI, 2017). In construction projects, risks must be audited continuously to deliver successful project outcomes. According to Shilts (2017), continuous auditing concentrates on testing for the pervasiveness of risk and the effectiveness of control and provides a more in-depth understanding of risks and controls from periodic project reviews. For example, continuous auditing includes performing trend analyses on a project's expense accounts to identify variances 
that management must act on in the event of a potential risk facing a project (Shilts, 2017). Continuous monitoring and continuous auditing can improve the risk management and control activities of virtually any project (Hardy \& Laslett, 2015). Although continuous auditing involves high implementation costs, the application of continuous auditing in construction projects improves accountability and risk control management (Eulerich \& Kalinichenko, 2018; Lombardi et al., 2014). It decreases the possibility of project cash flow being manipulated, improves fraud deterrence due to greater oversight, strengthens vendor relations, creates more effective procedures, stabilizes risk controls, and minimizes inherent risks. Additionally, project risk audits help improve the project's performance, enhance customer and stakeholder satisfaction, save costs, control scope to avoid scope creep, provide early problem diagnostics, clarify performance, cost, and schedule relationships (Obondi, 2020b). Risk audits identify future opportunities for improvement, evaluate the performance of the project team, inform the client of project status/prospects, and reconfirm the feasibility of commitment to the project.

\subsubsection{Contingency Reserves Analysis}

A contingency reserve is a budget within the project performance measurement baseline allocated to mitigate risks identified (PMI, 2017). Thus, a contingency reserve budget is created to respond to potential risks and uncertainties and help keep projects on budget (Touran \& Liu, 2015). They are included in project budgets to manage risk and achieve project goals (Ford, 2002). Contingency funds are usually estimated at the project planning phase. They are included in the original budget as escrow accounts to manage uncertainties and risks that may lead to deviations from a project's original time, cost, and quality objectives (De Marco et al., 2015). Contingency reserves are resources that include time, person, and capital to be assigned above the previously estimated amounts for a project to reduce the risk of cost or schedule overruns (Chang, 2012).

Reserve analysis compares the remaining contingency reserves against the risk remaining in a project to determine if the remaining reserves are adequate to cover risks and uncertainties (PMI, 2017). A failure in estimating, allocating, or managing the contingency over project duration could lead to project delays or cost overruns (Salah \& Moselhi, 2015a). Such problems can be avoided using methods that allow project stakeholders to estimate, allocate, control, and manage a contingency adequately. The most common contingency evaluating methods used to allocate contingency funds include deterministic, modern mathematics, and probabilistic methods (Bakhshi \& Touran, 2014).

Douglas (2001) argued that contingency planning and contingency budget management, when correctly implemented, help prevent or cover project uncertainties. The prevention of disturbances in deadlines of scheduled project work still relies on various types of reserves, but mainly on reserves of time (Turskis et al., 2012). Reserves are crucial for the management of scheduling risks (Obondi, 2020a). Karlsen and Lereim (2005) found that reserves or contingencies represent the additional funding required to account for the cost of risk. Schedule risks may be mitigated by including schedule contingency (i.e., extra time) and the costs attributable to schedule contingency in the project baseline (Douglas, 2001).

According to Figueiredo and Kitson (2009), estimating contingency is part of the risk management process. Therefore, contingency reserves should be expended and controlled like any other control account in the budget contingency management during project execution to monitor and control risk responses. The lack of contingency funds in construction projects results in cost overruns, difficulty in contingency management, an abandonment of the project due to lack of adequate funds, or a delay in the use of the project for business or social benefit (Otali \& Odesola, 2014). Providing enough contingency reserves in terms of capital, people, and time is essential to reduce project risks (Chang, 2012).

Project leadership plays a vital role in the planning and managing of contingency reserves in project monitoring and control. The amount of contingency contained in project control plans depends on whether the project leader is willing to accept the risk of project overruns (Eldosouky et al., 2014). The less risk a project leader is willing to accept, the more contingencies should be applied to project control plans. Van Niekerk and Bekker (2014) noted that construction project portfolios are risky by nature as many activities affect their outcomes. Therefore, contingency cost and duration must be allocated to the budget and duration of each project to provide for the possible impact of risks.

Furthermore, contingency budgets must be estimated and revised during a project as a continuous and dynamic management process (De Marco et al., 2015). The contingency management process should be emphasized within the project management framework to protect the interests of the various project stakeholders, including the community, creditors, investors, owners, and top managers. In construction project management, the contingency reserve accounts must not be viewed only as future costs for unforeseen events but also as potential opportunities for releasing the unspent contingency as a profit or adding improvements to the constructed facility.

\subsubsection{Risk Status Meetings}

Chen (2011) argued that project meetings are necessary for a modern society. Chen proposed that the meetings-flow approach (MFA) shows that meetings can enhance project management performance with careful planning and organization. In particular, MFA improves project monitoring by providing proper channels for communication in a typical project. As 
MFA continues in operation, so does the process of risk communication and intervention. Risk status meetings are meant for discussions and awareness about risk status in a project (PMI, 2017). Tuan-Hock et al. (2013) suggested that a risk management committee (RMC) has a significant bearing on risk management, and a monitoring board is needed to deal with risk in a project. Intrinsically, incorporating an RMC as part of the corporate governance mechanism is crucial for companies to control and manage risks.

In construction projects, the absence of coordination and interaction among project participants contributes to accidents and health hazards for project workers (Ghosh, 2014). One way to resolve this shortfall is to increase the involvement of project participants and augment interactions through a formal daily huddle meeting. The utilization of a formal daily huddle meeting in projects effectively improves the interaction and safety awareness among project workers. Formal daily huddle meetings provide a means of understanding the daily scope of project work and help project workers focus on expectations for safety and the work to be accomplished, thus boosting both the workers' productivity and security (Ghosh, 2014; Obondi, 2020a). During construction tendering, Laryea (2013) found that tender review meetings contribute significantly to the cost of tendering. Nonetheless, tender review meetings facilitate the joint development of tender submissions and minimize the risk of getting a tender calculation wrong. Hence, tender review meetings represent a risk-cost-benefit analysis that contractors must examine carefully for each tender process during tender development and submission.

\section{Research Method and Design}

This study used a quantitative non-experimental correlational design to address the research problem. Quantitative research techniques are used to test hypotheses, evaluate findings, generalize findings to a population, and encourage replication of the findings (Park \& Park, 2016). Quantitative methods are efficient in procuring large amounts of data within a given time (McCusker \& Gunaydin, 2015). Since this study was focused on testing hypotheses and generalizing the results, qualitative methods were not suitable because they do not test hypotheses and generalize research findings (McCusker \& Gunaydin, 2015). Although mixed methods could have been used in this study, using mixed methods can be expensive and timeconsuming, especially when gathering qualitative and quantitative data simultaneously (Obondi, 2020a).

This study used a non-experimental design. Unlike experimental designs, non-experimental designs do not directly manipulate variables as in a real experiment (Curtis et al., 2016; Podsakoff \& Podsakoff, 2019). Non-experimental designs use inferential statistics to establish associations. Furthermore, experimental research may be too costly and raise ethical concerns, especially when a researcher manipulates and controls variables (Podsakoff \& Podsakoff, 2019).

A correlational design was the preferred methodology for this study. Correlational studies explore and examine relationships between and among variables (Curtis et al., 2016). Correlational studies allow a researcher to understand the relationship between variables better. For example, this study explored and observed the relationship between risk audits and project success in construction projects. In the descriptive research design, this would be impossible as this design does not allow for the identification of relationships between variables. Therefore, considering the nature of the research question, this current study used a quantitative non-experimental correlational design to answer the research problem and its research questions.

The research questions for this study were structured to examine if a relationship exists between the utilization of the fourproject risk monitoring and control practices and project success in construction projects. The four-project risk monitoring and control practice variables included risk reassessment, risk audits, contingency reserves analysis, and risk status meetings, which acted as the independent variables. At the same time, project success was the dependent variable. The research tested the hypotheses to determine if a statistically significant relationship existed between the independent and the dependent variables. Fig. 1 presents the research model for this study.

Independent variable

\begin{tabular}{|l|l|l|}
\hline Project Risk Monitoring and Control Practices \\
- Risk Assessment \\
- Risk Audits \\
- Contingency Reserve Analysis \\
- Risk Status Meetings
\end{tabular}$\quad \longrightarrow$\begin{tabular}{cl} 
Project Success \\
$\bullet$ & Schedule Performance \\
$\bullet$ & Cost Performance \\
$\bullet$ & Customer Satisfaction \\
$\bullet$ & Business Success \\
\hline
\end{tabular}

Fig. 1. Research model 


\subsection{Population and Sample}

This research study took place in the Dallas-Fort Worth area of Texas. The study included construction project managers who met the following criteria: each construction project manager (a) must have been currently employed as a project manager and had a minimum of three years of experience managing construction projects, (b) must have managed risk on a completed construction project, (c) must have possessed an academic or professional qualification or a bachelor's degree or higher, and (d) must have been employed in a construction company in the Dallas-Fort Worth area. Given the study's problem, purpose, and research question, the construction project managers were selected as a unit of analysis given their knowledge of project management.

To recruit participants, the researcher used Qualtrics company. This research website company allows participants to complete a survey during the data collection process confidentially. Construction project managers were recruited through the Qualtrics research company's website. Qualtrics provided the sample frame, and construction project managers who were members of Qualtrics' expert panels that fit the sample frame were selected and invited to participate in the study.

A probability random sampling design whereby each population element has an equal chance of selection was used. According to Polit and Beck (2010), random sampling enables generalization in evidence-based practice and provides relevance of the research for people outside the sample under study. A total of 63 construction project managers participated in this study, all of whom responded to an online survey using Qualtrics as an interface platform for the research. Of the 63 responses received, 50 responses were complete. Therefore, the usable sample size for this study was 50 respondents.

\subsection{Instrumentation}

For this study, a reliable and valid survey instrument that could be used to examine whether the utilization of project risk monitoring and control practices was related to project success in construction projects could not be found. As a result, the researcher developed a new survey instrument for use in the current quantitative correlational study. The creation of the survey instrument for the current study relating to project risk monitoring and control practices and project success entailed several theoretical constructs, as identified in the earlier studies of De Marco and Thaheem (2013) and Jayasudha et al. (2014). The emphasis placed on the content was based on studies by D'souza (2012), El-Sayegh (2014), and Ryor (2013) relating to project risk management practices. The survey also included theoretical constructs relating to project success as outlined in the studies of Shenhar and Dvir (2007), Besteiro et al. (2015), Williams (2016), and Sohu et al. (2018).

Since a new survey instrument was developed for this study, a field test was required to establish the content and face validity of the survey instrument (Obondi, 2020a). Before collecting data, a panel of three experts reviewed the survey instrument - two professors in the project management field with knowledge of project management and one research consultant with knowledge of the academic research process. These professionals were selected from outside the study population to avoid conflict of interest and bias in research. These experts were asked to review the survey questions to ensure the questions were accurate, appropriate, and logically sequenced. The experts' recommendations regarding the survey questions were applied to improve the survey instrument.

A 5-point Likert scale with potential response ranging from $1=$ Strongly disagree to $5=$ Strongly agree was used, and participants were required to respond accordingly. A Likert scale is a psychometric measurement scale widely used in survey research in which respondents specify their level of agreement with a statement (Jayasudha et al., 2014). Using the survey method, researchers seek explanations and predictions from research participants to establish, confirm or validate relationships, and generalize the existing theories' contributions (Leedy \& Ormrod, 2013). Since risks are prevalent in construction projects and affect construction project performance, this survey was conducted to examine whether project risk monitoring and control practices are related to project success in the construction industry.

\subsection{Measurement of Variables}

The independent variables measured in this study were the four project risk monitoring and control practices: risk reassessment, risk audits, contingency reserves analysis, and risk status meetings, and project success as the dependent variable. Risk reassessment was measured using the frequencies (in terms of percentages) of usage of the risk reassessment method to examine whether project managers use this technique to review risks and determine risk levels in construction projects. Risk audits were measured using frequencies (in terms of percentages) of usage of a risk audit technique to understand better if project managers account for and utilize risk audit planning in construction projects. Contingency reserves were measured using frequencies (in terms of percentages) of usage of contingency reserves analysis technique to understand better if project managers account for and utilize contingency reserves to mitigate identified risks in construction projects. Risk status meetings were measured using frequencies (in terms of percentages) of the usage of the risk status meetings technique to examine whether project managers use this technique to review risks and determine risk trends in construction projects. In this study, project success (the dependent variable) was measured based on the project success dimensions of 
schedule, cost, customer satisfaction, and business success as outlined in the previous studies of Shenhar, Levy, and Dvir (1997) and Todorovic et al., (2015).

\section{Results}

To determine the reliability of the survey instrument, Cronbach's alpha coefficient values were examined for reliability and to measure the consistency and stability of the variables and confirm the internal consistency of the scales (Obondi, 2020a). Many researchers use Cronbach's alpha to measure the validity and reliability of an instrument, with a value of .70 or above considered desirable (Taber, 2017). Sekaran and Bougie (2016) pointed out that a Cronbach's alpha value closer to 1.00 signified better data reliability. Ullman (2007) and Hair (2007) suggested that the minimum acceptable coefficient alpha value for a study was .70. In this study, the analysis of the 32 Likert-type items on the survey instrument indicated that Cronbach's alpha was .958 , which was excellent regarding the internal consistency reliability. The results of Cronbach's alpha are shown in Table 1.

Table 1

Cronbach's Alpha

\begin{tabular}{cc}
\hline Cronbach's Alpha & Number of Items \\
\hline .958 & 32 \\
\hline
\end{tabular}

Before conducting statistical analysis, a review of the data set was necessary to validate the assumptions of normality and linearity of the data distributions for the correlated variables (i.e., risk reassessment, risk audits, contingency reserves analysis, risk status meetings, schedule performance, cost performance, customer satisfaction, and business success). There are many methods available to test for normality. Skewness and kurtosis statistics were selected to test the variables for normality in this study. Both kurtosis and skewness have ranges for normal data. Kurtosis represents the extent to which observations collect around a central mean (Obondi, 2020a). Kurtosis values should range from +3 to -3 to be considered normal (Coakes \& Steed, 2009). Skewness measures the asymmetry of the distribution of value around the mean (Obondi, 2020a). Skewness should range from +1 to -1 to be considered normal (Hair et al., 2007). However, Kline (2005) proposed that if a skewness value was located between +3 and -3 , then the value would be acceptable. In this current study, if either statistic was above an absolute value of 2.0, the assumption of normality was violated. Table 2 shows the results of the skewness and kurtosis test for normality.

Table 2

Skewness and Kurtosis Test for Normality

\begin{tabular}{lcc}
\hline Variable & Skewness & Kurtosis \\
\hline Risk Reassessment & -1.77 & 4.41 \\
Risk Audits & -1.45 & 4.25 \\
Contingency Reserves Analysis & -1.68 & 4.29 \\
Risk Status Meetings & -1.86 & 3.81 \\
Schedule Performance & -0.82 & 0.13 \\
Cost Performance & -0.37 & -0.44 \\
Customer Satisfaction & -0.55 & -0.51 \\
Business Success & -0.77 & 0.90 \\
\hline
\end{tabular}

The kurtosis statistics in Table 2 indicated that the statistical assumption of normality was violated for the four independent variables (risk reassessment, risk audits, contingency reserves analysis, and risk status meetings). However, for each of the four components of project success (schedule performance, cost performance, customer satisfaction, and business success), the assumption of normality was met. Since the normal distribution was violated, a non-parametric Spearman's rho correlation analysis was used in this study rather than the traditional Pearson's correlation. Spearman's rho correlation analysis does not assume normal data distribution (Obondi, 2020a).

\subsection{Descriptive Statistics}

This study examined responses from 50 participants. Many participants held a project manager position (39, 78\%) and were between 30 to 40 years $(26,52 \%)$. Most participants held a bachelor's degree $(33,66 \%)$. A majority of participants had a certificate in construction management $(32,64 \%)$. Most participants were male $(39,78 \%)$. Many participants had 6 to 10 years of experience $(17,34 \%)$ in managing construction projects. Table 3 shows the frequencies and percentages of the participants' demographics. 
Table 3

Frequencies and percentages of demographics

\begin{tabular}{|c|c|c|}
\hline Variable & Level & Frequency (\%) \\
\hline \multirow{5}{*}{ Age } & $18-29$ & $11(22)$ \\
\hline & $30-40$ & $26(52)$ \\
\hline & $41-50$ & $8(16)$ \\
\hline & $51-60$ & $4(8)$ \\
\hline & $61-65$ & $1(2)$ \\
\hline \multirow{2}{*}{ Gender } & Female & $11(22)$ \\
\hline & Male & $39(78)$ \\
\hline \multirow{5}{*}{$\begin{array}{l}\text { Years of } \\
\text { Experience }\end{array}$} & $3-5$ years & $11(22)$ \\
\hline & $6-10$ years & $17(34)$ \\
\hline & $11-15$ years & $14(28)$ \\
\hline & $16-20$ years & $7(14)$ \\
\hline & $21+$ years & $1(2)$ \\
\hline \multirow{5}{*}{ Education } & High school & $1(2)$ \\
\hline & Associate's degree & $1(2)$ \\
\hline & Bachelor's degree & $33(66)$ \\
\hline & Master's degree & $13(26)$ \\
\hline & Doctoral degree & $2(4)$ \\
\hline \multirow{5}{*}{ Job Title } & Project Manager & $39(78)$ \\
\hline & Project Coordinator & $2(4)$ \\
\hline & Project Analyst & $1(2)$ \\
\hline & Project Leader & $1(2)$ \\
\hline & Project Risk Manager & $7(14)$ \\
\hline \multirow{13}{*}{$\begin{array}{l}\text { Qualifications or } \\
\text { Certifications }\end{array}$} & Certificate in Construction Project Management & $32(64)$ \\
\hline & Capability Maturity Model Integration & $10(20)$ \\
\hline & Certificate in Project Management & $27(54)$ \\
\hline & Certificate in Risk Management & $24(48)$ \\
\hline & Certified Associate in Project Management & $13(26)$ \\
\hline & Information Technology Infrastructure Library & $14(28)$ \\
\hline & PMI Scheduling Professional & $3(6)$ \\
\hline & Program Management Professional & $7(14)$ \\
\hline & Project Management Professional & $15(30)$ \\
\hline & Projects in Controlled Environments (PRINCE2) & $5(10)$ \\
\hline & Six Sigma Black Belt & $6(12)$ \\
\hline & Six Sigma Green Belt & $4(8)$ \\
\hline & None of the above & $3(6)$ \\
\hline
\end{tabular}

A review of the descriptive statistics of the eight constructs in this study was also completed (see Table 4). Means and standard deviations conducted on the five variables indicated that customer satisfaction scores had the largest mean $(\mathrm{M}=$ 4.34), followed by business success scores $(\mathrm{M}=4.31)$ with the lowest standard deviations of 0.56 and 0.52 , as shown in Table 4 below. A low standard deviation indicates that the values tend to be close to the mean (also called the expected value) of the set.

Table 4

Descriptive statistics of constructs

\begin{tabular}{lcc}
\hline Variable & Mean & SD \\
\hline Risk Reassessment & 4.26 & 0.85 \\
Risk Audits & 4.22 & 0.79 \\
Contingency Reserves Analysis & 4.28 & 0.83 \\
Risk Status Meetings & 4.24 & 0.98 \\
Schedule Performance & 4.20 & 0.66 \\
Cost Performance & 4.11 & 0.60 \\
Customer Satisfaction & 4.34 & 0.56 \\
Business Success & 4.31 & 0.52 \\
\hline
\end{tabular}




\subsection{Inferential Statistics}

To answer the research questions in this study, SPSS version 26 software was used to perform the statistical analysis of the data collected. A non-parametric Spearman's rho correlation analysis was performed to test significant associations between the independent and dependent variables. Statistical significance was assumed at an alpha value of .05. The correlation analyses were interpreted and reported using a correlation matrix. Spearman's rho correlation interpretation is similar to Pearson's (e.g., the closer $r$ is to \pm 1 , the stronger the monotonic relationship). Correlation is effect size, and the strength of association can be explained using the following terms and values: .00-.19 "very weak," .20-.39 "weak," .40-.59 "moderate," .60-.79 "strong," and .80-1.0 "very strong" (Laerd Statistics, 2018). These terms are used whether the value is + or (Laerd Statistics, 2018; Schober et al., 2018). Also, correlation is expressed as a positive/negative relationship with the appropriate strength term applied (Schober et al., 2018).

To address research question 1, Spearman's rho correlation analysis was used to analyze data. The results from the analysis indicated a positive and significant association between risk reassessment and the four components of project success: schedule performance $(r h o=.49, p=.001)$, cost performance $(r h o=.50, p=.001)$, customer satisfaction $(r h o=.64, p=$ $.001)$, and business success ( $r h o=.54, p=.001$; see Table 5).

Table 5

Correlations: Risk Reassessment and Project Success Outcomes (Schedule Performance, Cost Performance, Customer Satisfaction, and Business Success)

\begin{tabular}{|c|c|c|c|c|c|c|c|}
\hline & & & $\begin{array}{c}\text { Risk } \\
\text { Reassessment }\end{array}$ & $\begin{array}{c}\text { Schedule } \\
\text { Performance }\end{array}$ & $\begin{array}{c}\text { Cost } \\
\text { Performance }\end{array}$ & $\begin{array}{c}\text { Customer } \\
\text { Satisfaction }\end{array}$ & $\begin{array}{l}\text { Business } \\
\text { Success }\end{array}$ \\
\hline \multirow[t]{3}{*}{$\begin{array}{l}\text { Spearman's } \\
\text { rho }\end{array}$} & \multirow[t]{3}{*}{$\begin{array}{c}\text { Risk } \\
\text { Reassessment }\end{array}$} & $\begin{array}{l}\text { Correlation } \\
\text { Coefficient }\end{array}$ & 1.000 & $.489 * *$ & $.503 * *$ & $.639 * *$ & $.540 * *$ \\
\hline & & Sig. (2-tailed) & & .000 & .000 & .000 & .000 \\
\hline & & $N$ & 50 & 50 & 50 & 50 & 50 \\
\hline
\end{tabular}

**Correlation is significant at the .01 level (2-tailed)

Based on the results from Table 5, the null hypothesis - that there is no positive relationship between risk reassessment and project success in construction projects - was rejected. The alternative hypothesis (H1a) was accepted. There was a positive relationship between the utilization of risk reassessment and project success in construction projects.

To address research question 2, Spearman's rho correlation analysis was used to analyze data. The results from the analysis indicated a positive and significant association between risk audits and the four components of project success: schedule performance $(r h o=.66, p=.001)$, cost performance $(r h o=.68, p=.001)$, customer satisfaction $(r h o=.76, p=$ $.001)$, and business success ( $r h o=.70, p=.001$; see Table 6$)$.

Table 6

Correlations: Risk Audits and Project Success Outcomes (Schedule Performance, Cost Performance, Customer Satisfaction, and Business Success)

\begin{tabular}{|c|c|c|c|c|c|c|c|}
\hline & & & $\begin{array}{c}\text { Risk } \\
\text { Audits }\end{array}$ & $\begin{array}{c}\text { Schedule } \\
\text { Performance }\end{array}$ & $\begin{array}{c}\text { Cost } \\
\text { Perfor- } \\
\text { mance }\end{array}$ & $\begin{array}{c}\text { Customer } \\
\text { Satisfaction }\end{array}$ & $\begin{array}{c}\text { Business } \\
\text { Success }\end{array}$ \\
\hline \multirow[t]{3}{*}{$\begin{array}{l}\text { Spearman's } \\
\text { rho }\end{array}$} & $\begin{array}{l}\text { Risk } \\
\text { Audits }\end{array}$ & $\begin{array}{l}\text { Correlation } \\
\text { Coefficient }\end{array}$ & 1.000 & $.663 * *$ & $.678 * *$ & $.757 * *$ & $.704 * *$ \\
\hline & & $\begin{array}{l}\text { Sig. (2- } \\
\text { tailed) }\end{array}$ & & .000 & .000 & .000 & .000 \\
\hline & & $N$ & 50 & 50 & 50 & 50 & 50 \\
\hline
\end{tabular}

**Correlation is significant at the .01 level (2-tailed)

Based on the results from Table 6, the null hypothesis, which indicated no positive relationship between risk audits and project success in construction projects, was rejected. In this case, the alternative hypothesis (H2a) was accepted. There was a positive relationship between the utilization of risk audits and project success in construction projects.

To address research question 3, Spearman's rho correlation analysis was used to analyze data. The results from the analysis indicated a positive and significant association between contingency reserves analysis and the four components of project success: schedule performance $(r h o=.52, p=.001)$, cost performance $(r h o=.47, p=.001)$, customer satisfaction $(r h o=.54, p=.001)$, and business success $(r h o=.55, p=.001$; see Table 7$)$. 
Table 7

Correlations: Contingency Reserves Analysis and Project Success Outcomes (Schedule Performance, Cost Performance, Customer Satisfaction, and Business Success)

\begin{tabular}{cccccccc}
\hline & & & $\begin{array}{c}\text { Contingency } \\
\text { Reserves } \\
\text { Analysis }\end{array}$ & $\begin{array}{c}\text { Schedule } \\
\text { Performance }\end{array}$ & $\begin{array}{c}\text { Cost } \\
\text { Performance }\end{array}$ & $\begin{array}{c}\text { Customer } \\
\text { Satisfaction }\end{array}$ & $\begin{array}{c}\text { Business } \\
\text { Success }\end{array}$ \\
\hline $\begin{array}{c}\text { Spearman's } \\
\text { rho }\end{array}$ & $\begin{array}{c}\text { Contingency } \\
\text { Reserves } \\
\text { Analysis }\end{array}$ & $\begin{array}{c}\text { Correlation } \\
\text { Coefficient }\end{array}$ & 1.000 & $.524 * *$ & $.474 * *$ & $.539^{* *}$ & $.553^{* *}$ \\
& Sig. (2-tailed) & & & .000 & .001 & .000 & .000 \\
& $N$ & 50 & 50 & 50 & 50 & 50 \\
\hline
\end{tabular}

**Correlation is significant at the .01 level (2-tailed).

Based on the results from Table 7, the null hypothesis, which indicated no positive relationship between contingency reserves analysis and project success in construction projects, was rejected. Instead, the alternative hypothesis (H3a) was accepted. There was a positive relationship between the utilization of contingency reserves analysis and project success in construction projects.

To address research question 4, Spearman's rho correlation analysis was used to analyze data. The results from the analysis indicated a positive and significant association between risk status meetings and the four components of project success: schedule performance ( $r h o=.57, p=.001)$, cost performance $(r h o=.51, p=.001)$, customer satisfaction $(r h o=.68$, $p=.001)$, and business success ( $r h o=.60, p=.001 ;$ see Table 8$)$

Table 8

Correlations: Risk Status Meetings and Project Success Outcomes (Schedule Performance, Cost Performance, Customer Satisfaction, and Business Success)

\begin{tabular}{|c|c|c|c|c|c|c|c|}
\hline & & & $\begin{array}{c}\text { Risk } \\
\text { Status } \\
\text { Meetings }\end{array}$ & $\begin{array}{c}\text { Schedule } \\
\text { Performance }\end{array}$ & $\begin{array}{c}\text { Cost } \\
\text { Performance }\end{array}$ & $\begin{array}{c}\text { Customer } \\
\text { Satisfaction }\end{array}$ & $\begin{array}{c}\text { Business } \\
\text { Success }\end{array}$ \\
\hline \multirow[t]{3}{*}{$\begin{array}{l}\text { Spearman's } \\
\text { rho }\end{array}$} & $\begin{array}{l}\text { Risk } \\
\text { Status }\end{array}$ & $\begin{array}{l}\text { Correlation } \\
\text { Coefficient }\end{array}$ & 1.000 & $.567 * *$ & $.505 * *$ & $.679 * *$ & $.602 * *$ \\
\hline & Meetings & Sig. (2-tailed) & & .000 & .000 & .000 & .000 \\
\hline & & $N$ & 50 & 50 & 50 & 50 & 50 \\
\hline
\end{tabular}

**Correlation is significant at the .01 level (2-tailed)

Based on the results from Table 8, the null hypothesis, which indicated that there is no positive relationship between risk status meetings and project success in construction projects, was rejected. Instead, the alternative hypothesis (H4a) was accepted. There was a positive relationship between the utilization of risk status meetings and project success in construction projects.

\section{Discussion}

The findings of this study were evaluated based on the four research questions in the current study. Based on research question 1, this study examined whether there was a relationship between the utilization of risk reassessment and project success in construction projects. Spearman's rho correlation analysis results indicated a positive and significant association between risk reassessment and the four components of project success: schedule performance $(r h o=.49, p=.001)$, cost performance $(r h o=.50, p=.001)$, customer satisfaction $(r h o=.64, p=.001)$, and business success $(r h o=.54, p=.001)$. These results showed that the relationship between the utilization of risk reassessment and the four components of project success was moderate on schedule performance, cost performance, business success, while strong on customer satisfaction (Laerd Statistics, 2018). These results confirmed that the usage of risk reassessment led to the project being completed on schedule, completed within budget, resulting in customer satisfaction with the quality of the end product, and also being identified as economic business success in terms of return on investment. The implications of this finding suggested that the construction project manager's utilization of the risk reassessment technique positively affected the success rate of projects in the construction industry. These findings align with previous studies on project risk reassessment, showing a positive relationship between project risk reassessment and project success. For example, these results are similar to Lavenson et al. (2017) study's findings, which indicated that periodic reassessment of risks optimized the schedule, captured cost savings, and added value to greenfield projects.

In research question 2, this study examined whether there was a relationship between the utilization of risk audits and project success in construction projects. Spearman's rho correlation analysis results showed a positive and significant association between risk audits and the four components of project success: schedule performance $(r h o=.66, p=.001)$, cost performance $(r h o=.68, p=.001)$, customer satisfaction $(r h o=.76, p=.001)$, and business success $(r h o=.70, p=.001)$. These results showed that the relationship between the utilization of risk audits and project success was strong in all four 
components of project success: schedule performance, cost performance, customer satisfaction, and business success. In this case, there was a statistically significant positive relationship between the utilization of risk audits and project success. These results confirmed that the usage of risk audits led to the project being completed on schedule, completed within budget, resulting in customer satisfaction, and identified as economic business success in terms of returns on investment. The implications of this finding suggested that the construction project manager's utilization of the risk audits technique positively affected the success rate of projects in the construction industry. These findings align with previous studies on project risk audits, showing a positive relationship between project risk audits and project success. For example, earlier studies by Eulerich and Kalinichenko (2018) and Lombardi et al. (2014) found that continuous risk auditing in construction projects improved a project's cash flow, accountability, and risk control.

Regarding research question 3, this study examined whether there was a relationship between the utilization of contingency reserves analysis and project success in construction projects. The Spearman's rho correlation analysis indicated a positive and significant association between contingency reserves analysis and the four components of project success: schedule performance $(r h o=.52, p=.001)$, cost performance $(r h o=.47, p=.001)$, customer satisfaction $(r h o=.54, p=.001)$, and business success ( $r h o=.55, p=.001)$. These results showed that the relationship between the utilization of contingency reserves analysis and project success was moderate in all four components of project success: schedule performance, cost performance, customer satisfaction, and business success. Although the utilization of contingency reserves analysis had a moderate correlation with project success, its frequent utilization led to the project being completed on schedule, completed within budget, resulting in customer satisfaction with the quality of the end product, and identified as economic business success in terms of returns on investment. The implications of this finding suggested that the construction project manager's utilization of contingency reserves analysis positively affects the success rate of projects in the construction industry. These findings align with previous studies on project contingency reserves analysis, showing a positive relationship between contingency reserves analysis and project success. For example, De Marco et al. (2015) asserted that contingency reserves could be utilized to reduce risks and meet project objectives such as scope, time, cost, quality, and customer satisfaction. Touran and Liu (2015) found that the usage of contingency reserves keeps projects on budget.

Finally, in research question 4, this study examined whether there was a relationship between the utilization of risk status meetings and project success in construction projects. The Spearman's rho correlation analysis results indicated a positive and significant association between risk status meetings and the four components of project success: schedule performance $(r h o=.57, p=.001)$, cost performance $(r h o=.51, p=.001)$, customer satisfaction $(r h o=.68, p=.001)$, and business success $(r h o=.60, p=.001)$. These results showed that the relationship between the utilization of risk status meetings and the four components of project success was moderate on schedule performance and cost performance and strong on customer satisfaction and business success. Although the utilization of risk status meetings had a moderate to strong correlation with project success, its frequent utilization led to the project being completed on schedule, completed within budget, resulting in the customer satisfaction with the quality of the end product, and identified as economic business success in terms of returns on investment. The implications of this finding suggested that the construction project manager's utilization of risk status meetings positively affected the success rate of projects in the construction industry. These findings align with previous studies on project risk status meetings, showing a positive relationship between project risk status meetings and project success. For example, a study conducted by Ghosh (2014) found that the utilization of a formal daily huddle meeting in construction projects improved project scope and boosted the workers' productivity and safety in a project. Laryea (2013) found that tender review meetings contribute significantly to the cost of construction project tendering by minimizing tender costs during tender development and submission.

However, this study is different from previous studies (Didraga, 2013; Pimchangthong \& Boonjing, 2017). For example, a study conducted by Didraga (2013) to investigate the relationship between risk management and information technology (IT) project success found a low-intensity correlation between the application of risk response monitoring and control and the subjective performance of the IT project in terms of reliability, easiness, flexibility, satisfaction, and quality. On the objective performance of the IT project, the author found that the correlation between risk response monitoring and control and schedule performance was not significant. Also, the author found that the correlation between risk response monitoring and control and cost performance was not considered significant. These findings confirmed that the application of risk response monitoring and control in the IT project was not related to IT project success. In a similar study, Pimchangthong and Boonjing (2017) explored how risk management practices that included risk identification, risk analysis, risk response planning, and risk monitoring and control influenced IT project success. The authors' study indicated that risk identification and risk response planning positively influenced the process performance, while risk analysis negatively influenced product performance. The study's results did not indicate whether risk monitoring and control influenced IT project success. However, based on the correlation analysis and interpretation of the results of the current study, it was found that all project risk monitoring and control practices that include risk reassessment, risk audits, contingency reserves analysis, and risk status meetings were significantly and positively related to project success in construction projects (Obondi, 2020a). In this case, since this was a non-experimental study, a correlation only established an association, not a causal relationship. 


\subsection{Recommendations for Practice}

One of the recommendations that emerged from this study was that construction project managers should recognize the importance of project risk monitoring and control practices and apply them to their projects to minimize risks for successful projects in the construction industry. This can be achieved by conducting periodic workshops and training project managers on the importance of risk monitoring and control practices. According to Tavakolan and Mohammadi (2018), a workshop allows the organization to identify critical risks. A workshop helps the organization staff better understand the project's environment and provides chances to improve teamwork. Also, in this case, training increases the project manager's awareness of risk, risk response, monitoring, and control strategies.

Another recommendation was that policymakers or organizations could use the results from this study as a training resource and putup training programs to improve project managers' skills in risk management, monitoring, and control through formal classes. Training organizations and educational institutions providing project management-related training programs should also develop curricula and training modules that include risk monitoring and control techniques supported by the findings of this study since we know that training programs help improve leadership and management skills in organizations (Obondi, 2020a). Obi-Anike and Ekwe (2014) found that effective training is an investment in an organization with immediate and long-term returns. Therefore, construction organizations need to effectively manage risk management training programs to gain returns from their investment. Construction organizations should make risk monitoring and control training a priority. To use risk monitoring and control training to gain a competitive advantage, organizations should view training broadly as a way to create intellectual capital (Obi-Anike \& Ekwe, 2014).

The final recommendation was that, in addition to project managers, all project participants must monitor and control risks in the construction industry. Using an enterprise risk management (ERM) framework (also known as integrated risk management model) can improve risk management in a project. Involving all project participants in risk monitoring provides the project management team with critical decision-making information and aids in tracking and monitoring high-risk areas so that problems can be predicted and mitigated quickly (Davis, 2007; Obondi, 2020a). An integrated risk management approach has an integrated capacity to monitor and control risks effectively (Liu et al., 2018).

\subsection{Limitations of the Study}

Limitations of the study are those factors that impact or influence the interpretations of the findings. The research method could be considered a limitation because the current methodology investigated statistical relationships between the variables and did not allow for any expanded thoughts or experiences the participants may have had (Queirós et al., 2017). However, the researcher ensured that the survey was administered in alignment with the study's problem, purpose, and research questions. The researcher administered the survey over the internet (Qualtrics website) via electronic mail, monitored responses as they were being returned, and sent reminders to non-respondents. This alignment ensured that the collected data would answer the research questions.

The second possible limitation was the time restriction since the researcher utilized a survey whereby respondents visited the Qualtrics website. For example, the survey might have seemed long (taking 15 to 20 minutes to complete). Some participants may not have completed the survey in its entirety due to time restraints. An incomplete survey could hinder the data collection process. In solving this limitation, the researcher ensured that the survey was easy to complete and contained understandable questions. The researcher also utilized skip logic that prevented the participants from skipping any questions. All incomplete surveys were eliminated from the study. The third and final limitation was that this study was restricted to construction project managers working for construction companies in the Dallas-Fort Worth area of Texas. So, the geographic specificity inherently confined the study.

\subsection{Recommendations for Future Research}

This study has several strengths that enhance the validity of the findings and add to the urgency for additional research in other sectors of the economy. Apart from the construction industry, it is recommended that future research should focus on the influence of project risk monitoring and control practices on project performance in other industries such as agriculture, healthcare, research and development, and education. Doing so will increase the generalizability of this current study's findings. According to Lalayants and Tripodi (2009), the repetition of the original research with different samples increases the generalizability of study findings. Understanding how project risk monitoring and control practices influence the performance of a project in different industries would aid organizations to manage, monitor, and control risks effectively and deliver successful projects.

Since this study was conducted in the United States, which is a developed country, it is recommended that future research be conducted in developing countries to see whether the findings from the study remain the same and generalizable. Developing countries have different cultures that could change or impact the results of their studies. Different cultures in 
developing countries may interpret their findings differently. However, conducting the same study in developing countries could improve the objectivity and generalizability of the findings of this study and add more insights and knowledge to improve risk management in organizations (Lalayants \& Tripodi, 2009).

Since this was a quantitative study, future studies could be conducted using mixed methods to explore this topic and see whether the findings remain the same. Mixed methods use both qualitative and quantitative methods in the same research. Using mixed methods to explore this topic further helps researchers avoid biases intrinsic to a single-method approach, compare qualitative and quantitative data, and improve the study's findings to produce a complete picture of the phenomenon being studied. McKim (2017) argued that studies that use a mixed-methods approach gain a deeper, broader understanding of the phenomenon than studies that do not utilize quantitative and qualitative approaches. The integration component of mixed methods gives readers more confidence in the results and the conclusions they draw from the study. Although mixed methods could be used in this study, using mixed methods can be expensive and time-consuming, especially when gathering qualitative and quantitative data simultaneously.

Finally, future studies should explore other project risk monitoring and control practices, such as tracking by risk department, use of case studies, decision analysis based on quantitative risk analysis outputs, incident investigation, safety and loss control review, and periodic risk register review (De Marco et al., 2015). Future studies should examine the impact of these project risk monitoring and control practices on project performance. Doing so will add or contribute more knowledge to the project management body of knowledge.

\section{Conclusion}

The utilization of project risk monitoring and control practices is essential to the growth and sustainability of the construction industry. The findings of this study concluded that there was a statistically significant positive relationship between risk reassessment and project success, a statistically significant positive relationship between the utilization of risk audits and project success, a significant positive relationship between contingency reserves analysis and project success, and a statistically significant positive relationship between risk status meetings and project success. Organizations can use these findings to formulate policies and procedures for solving project risk management issues that will ensure the successful completion of their projects. Frequent training on risk monitoring and control practices is necessary to increase the awareness of risks and increase project success. By understanding the relationship between the utilization of project risk monitoring and control practices and project success, project managers can be better prepared to apply these practices to manage and solve risks in their area of practice.

For the utilization of project risk monitoring and control practices to yield benefits in the construction industry, all project participants must be involved in monitoring and controlling risks. Using an integrated risk management (also known as enterprise risk management) model can improve the ability and performance of project risk management in the construction industry. Integrated risk management has an integrated capacity to effectively monitor and control risks (Liu et al., 2018) while affirming the importance of completing risk reassessments, utilizing risk audits, participating in contingency reserves analysis, and holding risk status meetings that aid in a project's success.

The correlation between project success and the utilization of project risk monitoring and control practices seemed to be strong, positive, and significant, as demonstrated in the results of this study. Although a correlational relationship did not prove causality, an increase in the usage of project risk monitoring and control practices increased project success. While research participants agreed that the use of project risk monitoring and control practices was a good idea, it seemed that project risk monitoring and control practices were not widely used, causing construction organizations to experience large financial deficits, sometimes up to $85 \%$ of the total cost of a project (Senesi et al., 2015). Although many project risk monitoring and control practices are available, many project managers ignore them or are reluctant to apply them in their projects. In this case, the lack of application of project risk monitoring and control practices resulted from the lack of awareness of the benefits of project risk monitoring and control practices.

Conversely, construction organizations should regularly give special attention to the use of project risk monitoring and control practices to improve the success rate of a project. Awareness, continuous application, and better training are needed to promote the understanding, use, and usefulness of project risk monitoring and control practices in construction projects. The results of this study indicated that the utilization of project risk monitoring and control practices, which included risk reassessment, risk audits, contingency reserves analysis, and risk status meetings, correlated with project success in construction projects. Therefore, as long as construction project managers are proactive and frequent in applying project risk monitoring and control practices in their daily project work, the utilization of project risk monitoring and control practices will continue to be part of a solution to many problems that exist in their projects. 


\section{Acknowledgments}

I would like to recognize and thank Dr. Randee L. Sanders, Dr. Harry Jackson, and Dr. Sharon Kimmel for their review and the informative feedback I received during my research process.

\section{References}

Alashwal, A. M., \& Al-Sabahi, M. H. (2018). Risk factors in construction projects during unrest period in Yemen. Journal of Construction in Developing Countries, 23(2), 43-62. doi:10.21315/jcdc2018.23.2.4.

Baharuddin, B., \& Yusof, M. M. (2017). Risk management practices for information system projects in the public sector. Presented at the 6th International Conference on Electrical Engineering and Informatics (ICEEI), 25-27, November, Langkawi, Malaysia.

Bakhshi, P., \& Touran, A. (2014). An overview of budget contingency calculation methods in construction industry. Procedia Engineering, 85 (Selected papers from Creative Construction Conference 2014), 52-60. doi:10.1016/j.proeng.2014.10.528.

Besteiro, E. C., Pinto, J. D., \& Novaski, O. (2015). Success factors in project management. Business Management Dynamics, 4(9), 19-34.

Cagliano, A. C., Grimaldi, S., \& Rafele, C. (2015). Choosing project risk management techniques. A theoretical framework. Journal of Risk Research, 18(2), 232-248. doi:10.1080/13669877.2014.896398.

Cakmak, P. I., \& Tezel, E. (2019). A guide for risk management in construction projects: Present knowledge and future directions. In N. Khatleli (Ed.), Risk Management in Construction Projects (pp. 600-613). doi:10.5772/intechopen.84361.

Carvalho, M. D., \& Rabechini, R., Jr. (2015). Impact of risk management on project performance: The importance of soft skills. International Journal of Production Research, 53(2), 321-340.

Chang, P. H. (2012). Applying resource capability for planning and managing contingency reserves for software and information engineering projects. 2012 IEEE International Conference on Electro/Information Technology, 1. doi:10.1109/EIT.2012.6220715.

Chapman, R. J. (2019). Exploring the value of risk management for projects: Improving capability through the deployment of a maturity model. IEEE Engineering Management Review, 47(3), 126-143.

Chen, C. (2011). Managing projects from a client perspective: The concept of the meetings-flow approach. International Journal of Project Management, 29(6), 671-686. doi:10.1016/j.ijproman.2010.07.007.

Coakes, S. J. and Steed, L. (2009). SPSS: Analysis without anguish using SPSS version 14.0 for Windows. New York, NY: John Wiley and Sons.

Construction Industry Institute. (2014). Performance assessment, 2014 Edition. Austin, TX: Construction Industry Institute.

Curtis, E. A., Comiskey, C., \& Dempsey, O. (2016). Importance and use of correlational research. Nurse Researcher, 23(6), 20-25.

Davis, D. C. (2007). Enterprise risk management and business activity monitoring program. Armed Forces Comptroller, 52(4), 44-45. Retrieved from https://search-ebscohost-com.proxy1.ncu.edu/login.aspx?direct=trueanddb=bthan$\mathrm{dAN}=27887169$ andsite $=$ eds-live.

De Marco, A., \& Thaheem, M. J. (2013). A survey on usage and diffusion of project risk management techniques and software tools in the construction industry. International Journal of Economics and Management Engineering, 7(6), 1383-1390. Retrieved from https://iris.polito.it/retrieve/handle/11583/2509565/60102/v78-191.pdf.

De Marco, A., Rafele, C., Thaheem, M. J. (2015). Dynamic management of risk contingency in complex design-build projects. Journal of Construction Engineering and Management, 142(2), 04015080. doi:10.1061/(ASCE)CO.19437862.0001052.

D'souza, C. (2012). Examining the relationship between project risk management and information technology (IT) project success (Order No. 3572898). Available from ProQuest Dissertations and Theses Global. (1433375409). Retrieved from https://proxy1.ncu.edu/login?url=https://search-proquest-com.proxy1.ncu.edu/docview/1433375409?accountid=28180.

Diab, M. F., Varma, A. \& Nassar, K. (2012). Using risk assessment to improve highway construction project performance. 48th ASC Annual International Conference Proceedings, Associated Schools of Construction.

Didraga, O. (2013). The role and the effects of risk management in IT project success. Informatica Economica, 17(1), 8698.

Douglas, E. E. (2001). Contingency management on DOE projects. AACE International Transactions, 1-6.

Eldosouky, I. A., Ibrahim, A. H., \& Mohammed, H. E. D. (2014). Management of construction cost contingency covering upside and downside risks. Alexandria Engineering Journal, 53(4), 863-881. doi:10.1016/j.aej.2014.09.008.

Eulerich, M., \& Kalinichenko, A. (2018). The current state and future directions of continuous auditing research: An analysis of the existing literature. Journal of Information Systems, 32(3), 31-51. doi:10.2308/isys-51813.

Fabricius, G., \& Buttgen, M. (2015). Project managers' overconfidence: How is risk reflected in anticipated project success? Business Research, 8(2), 239-263.

Figueiredo, F. C., \& Kitson, B. (2009). Defining risk and contingency for pipeline projects. AACE International Transactions, $8(1), 1-10$. 
Ford, D. N. (2002). Achieving multiple project objectives through contingency management. Journal of Construction Engineering and Management, 128(1), 30. doi:10.1061/(ASCE)0733-9364(2002)128:1(30).

Ghosh, S. (2014). Does formal daily huddle meetings improve safety awareness? International Journal of Construction Education and Research, 10(4), 285-299. doi:10.1080/15578771.2014.886642.

Grigore, M. C., Ionescu, S., \& Niculescu, A. (2018). New methods for project monitoring. FAIMA Business and Management Journal, 6(1), 35-44.

Hair, J. F., Money, A.H., Samouel, P., \& Page, M. (2007). Research methods for business. Chichester, England: John Wiley and Sons.

Haji-Kazemi, S., Andersen, B., \& Krane, H. P. (2013). A review on possible approaches for detecting early warning signs in projects. Project Management Journal, 44(5), 55-69. doi:10.1002/pmj.21360.

Hardy, C. A., \& Laslett, G. (2015). Continuous auditing and monitoring in practice: Lessons from Metcash's business assurance group. Journal of Information Systems, 29(2), 183-194. doi:10.2308/isys-50969.

Jayasudha, K., Vidivelli, B., \& Surjith, E.R.G. (2014). Risk assessment and management in construction projects. International Journal of Scientific and Engineering Research. 5(8), 387-96.

Karlsen, J. T., \& Lereim, J. (2005). Management of project contingency and allowance. Cost Engieering, 47(9), 24-29.

Khan, R. A. \& Gul, W. (2017). Empirical study of critical risk factors causing delays in construction projects. Presented at the 9th IEEE International Conference on Intelligent Data Acquisition and Advanced Computing Systems: Technology and Applications (IDAACS, 21-23 September 2017), Bucharest, Romania. doi:10.1109/IDAACS.2017.8095217.

Kline, R. B. (2005). Principles and practice of structural equation modeling. New York, NY: Guilford Press.

Kommunuri, J., Narayan, A., Wheaton, M., Jandug, L., \& Gonuguntla, S. (2016). Firm performance and value effects of enterprise risk management. New Zealand Journal of Applied Business Research, 14(2), 17-28. Retrieved from http://search.informit.com.au/ fullText;dn=797918171949834;res=IELNZC.

Laerd Statistics (2018). Spearman's correlation using SPSS statistics. Statistical tutorials and software guides. Retrieved from https://statistics.laerd.com/

Lalayants, M., \& Tripodi, T. (2009). A review of generalization methods used in empirical social work literature. International Journal of Social Welfare, 18(4), 333.

Laryea, S. (2013). Nature of tender review meetings. Journal of Construction Engineering and Management, $139(8), 927$. doi:10.1061/\%28ASCE\%29CO.1943-7862.0000662.

Lavenson, D. M., Venkatesan, R., Young, M. K., \& Kebert, N. (2017, May 1). The Importance of Periodic Reassessment of Operational Strategies for Wax Management. Offshore Technology Conference. doi:10.4043/27532-MS.

Leedy, P. D., \& Ormrod, J. E. (2013). Practical research: Planning and design. Saddle River, NJ: Merrill.

Liu, J., Low, S. P., \& Zhang, Q. (2018). Enterprise risk management practices of top ENR international contractors. International Journal of Construction Management, 18(5), 364-374. doi:10.1080/15623599.2017.1326299.

Lombardi, D. R., Vasarhelyi, M. A., \& Verver, J. (2014). Continuous controls monitoring: A case study. Journal of Emerging Technologies in Accounting, 11(1), 83-98. doi:10.2308/jeta-51006.

Mamoghli, S., Goepp, V., \& Botta-Genoulaz, V. (2015). An operational "risk factor-driven" approach for the mitigation and monitoring of the "misalignment risk" in enterprise resource planning projects. Computers in Industry, 70, 1-12. doi:10.1016/j.compind.2015.01.010.

Mandru, L. (2016). How to control risks? Towards a structure of enterprise risk management process. Journal of Public Administration, Finance and Law, 9, 80-92.

McCusker, K., \& Gunaydin, S. (2015). Research using qualitative, quantitative, or mixed methods and choices based on the research. Perfusion, 30(7), 537-542. doi:10.1177/0267659114559116.

McKim, C. A. (2017). The value of mixed methods research: A mixed methods study. Journal of Mixed Methods Research, 11(2), 202-222.

Ning, Y., \& Mao, Y. (2011). The risk monitoring of coal construction project based on system dynamics model. In Proceedings of the International Conference on Information Systems for Crisis Response and Management (pp. 330-334). New York, NY: IEEE. doi:10.1109/ISCRAM.2011.6184127.

Obi-Anike, H. O., \& Ekwe, M. C. (2014). Impact of training and development on organizational effectiveness: Evidence from selected public sector organizations in Nigeria. European Journal of Business and Management, 6(29), 66-75.

Obondi, K. C. (2020a). The Relationship Between Project Risk Monitoring, Control Practices, and Project Success in Construction Projects (Unpublished Doctoral dissertation, Northcentral University).

Obondi K. C. (2020b). The impact of project risk audits on construction project success. Journal of Engineering Management and Competitiveness (JEMC), 10(2), 103- 115.

Otali, M., \& Odesola, I. A. (2014). Effectiveness evaluation of contingency sum as a risk management tool for construction projects in Niger Delta, Nigeria. Ethiopian Journal of Environmental Studies and Management, 7(6), 588-598. doi:10.4314/ejesm.v7i6.1.

Park, J., \& Park, M. (2016). Qualitative versus quantitative research methods: Discovery or justification? Journal of Marketing Thought, 3(1), 1-7. doi:10.15577/jmt.2016.03.01.1.

Pimchangthong, D., \& Boonjing, V. (2017). Effects of risk management practices on IT project success. Management and Production Engineering Review, 8(1), 30-37. doi:10.1515/mper-2017-0004. 
Podsakoff, P. M., \& Podsakoff, N. P. (2019). Experimental designs in management and leadership research: Strengths, limitations, and recommendations for improving publishability. The Leadership Quarterly,30(1), 11-33. doi:10.1016/j.leaqua.2018.11.002.

Polit, D. F., \& Beck, C. T. (2010). Generalization in quantitative and qualitative research: Myths and strategies. International Journal of Nursing Studies, 47(11), 1451-1458. doi:10.1016/j.ijnurstu.2010.06.004.

Project Management Institute. (2009). Practice standard for project risk management $\left(4^{\text {th }} \mathrm{ed}\right)$. Newtown Square, PA: Project Management Institute.

Project Management Institute. (2011). Top ten mistakes made in managing project risks. Retrieved from https://www.pmi.org/learning/library/mistakes-made-managing-project-risks-6239.

Project Management Institute. (2013). A guide to the project management body of knowledge (PMBOK ${ }^{\circledR}$ Guide) $^{\left(5^{\text {th }}\right.}$ ed.) Newtown Square, PA: Project Management Institute.

Project Management Institute. (2017). A guide to the project management body of knowledge (PMBOK ${ }^{\circledR}$ Guide) $^{\left(6^{\text {th }}\right.}$ ed.). Newtown Square, PA: Project Management Institute.

Qazi, A., Quigley, J., Dickson, A., \& Kirytopoulos, K. (2016). Project complexity and risk management (ProCRiM): Towards modeling project complexity driven risk paths in construction projects. International Journal of Project Management, 34(7), 1183-1198. doi:10.1016/j.ijproman.2016.05.008.

Queirós, A., Faria, D., \& Almeida, F. (2017). Strengths and limitations of qualitative and quantitative research methods. European Journal of Education Studies, 3(9), 369-386.

Ryor, M. M. (2013). Utilization of risk management practices by construction project managers in the United States (Order No. 3567627). Available from ProQuest Dissertations and Theses Global. (1424273936). Retrieved from https://proxy1.ncu.edu/login?url=https://search-proquest-com.proxy1.ncu.edu/docview/1424273936?accountid=28180.

Salah, A., \& Moselhi, O. (2015a). Contingency modeling for construction projects using fuzzy-set theory. Engineering Construction and Architectural Management, 22(2), 214-241. doi:10.1108/ECAM-03-2014-0039.

Salah, A., \& Moselhi, O. (2015b). Risk monitoring and control in construction projects. Presented at 2015 AACE International Annual Meeting, Las Vegas, NV. Available from https://www.pathlms.com/aace/courses/3172/video_presentations $/ 34477$.

Schober, P., Boer, C., \& Schwarte, L.A. (2018). Correlation coefficients: Appropriate use and interpretation. Anesthesia and Analgesia, (126)5, 1763-1768. doi:10.1213/ANE.0000000000002864.

Sekaran, U., \& Bougie, R. (2016). Research methods for business. A skill building approach (7 ${ }^{\text {th }}$ ed.). Chichester, England: John Wiley and Sons.

Senesi, C., Javernick-Will, A., \& Molenaar, K. R. (2015). Benefits and barriers to applying probabilistic risk analysis on engineering and construction projects. Engineering Management Journal, 27(2), 49-57. doi:10.1080/10429247.2015.1035965.

Serpell, A., Ferrada, X., \& Rubio, N. L. (2017). Fostering the effective usage of risk management in construction. Journal of Civil Engineering and Management, 23(7), 858-867. doi:10.3846/13923730.2017.1321578.

Sharma, S. K. (2013). Risk management in construction projects using combined analytic hierarchy process and risk map framework. IUP Journal of Operations Management, 12(4), 23-53. doi:10.1177/097324701100700310.

Shenhar, A. J., Levy, O., \& Dvir, D. (1997). Mapping the dimensions of project success. Project management journal, $28(2), 5-13$.

Shenhar, A. J., \& Dvir, D. (2007). Reinventing project management: The diamond approach to successful growth and innovation. Boston, MA: Harvard Business School Press.

Shilts, J. (2017). A framework for continuous auditing: Why companies don't need to spend big money. Journal of Accountancy, 223(3), 1-7.

Sigmund, Z. \& Radujkovic, M. (2016). Risk management tool for improving project flows for construction projects on existing buildings. e-gfos, 7(12), 76-85. Retrieved from http://e-gfos.gfos.hr/app/storage/protected/42-12-06-2017-0659-13-paper-9-sigmund.pdf.

Sohu, S., Jhatial, A. A., Ullah, K., Lakhiar, M. T., \& Shahzaib, J. (2018). Determining the critical success factors for highway construction projects in Pakistan. Engineering, Technology and Applied Science Research, 8(2), 2685-2688. Retrieved from https://www.etasr.com/index.php/ETASR/article/view/1866/pdf.

Taber, K. (2017). The use of Cronbach's alpha when developing and reporting research instruments in science education. Research in Science Education, 48(6), 1273-1296. doi:10.1007/s11165-016-9602-2.

Tavakolan, M., \& Mohammadi, A. (2018). Risk management workshop application: a case study of Ahwaz Urban Railway project. International Journal of Construction Management, 18:3, 260-274. doi:10.1080/15623599.2017.1325112

Todorovic, M. L., Petrovic, D. C., Mihic, M. M., Obradovic, V. L., \& Bushuyev, S. D. (2015). Project success analysis framework: A knowledge-based approach in project management. International Journal of Project Management, 33(4), 772-783. doi:10.1016/j.ijproman.2014.10.009

Touran, A., \& Liu, J. (2015). A method for estimating contingency based on project complexity. Procedia Engineering, 123, 574-580. doi:10.1016/j.proeng.2015.10.110.

Tuan-Hock Ng, Lee-Lee, C., \& Ismail, H. (2013). Is the risk management committee only a procedural compliance? The Journal of Risk Finance, 14(1), 71-86. doi:10.1108/15265941311288112. 
Turskis, Z., Gajzler, M., \& Dziadosz, A. (2012). Reliability, risk management, and contingency of construction processes and projects. Journal of Civil Engineering and Management, 18(2), 290-298. doi:10.3846/13923730.2012.672931.

Ullman, J. B. (2007). Structural equation modeling. In B.G. Tabachnick and L.S. Fidell, Using multivariate statistics $\left(5^{\text {th }}\right.$ ed., pp. 676-780). Boston, MA: Allyn and Bacon.

Van Niekerk, M., \& Bekker, J. (2014). Developing a tool for project contingency estimation in a large portfolio of construction projects. South African Journal of Industrial Engineering, (3), 96-111. doi:10.7166/25-3-905.

Williams, T. (2016). Identifying success factors in construction projects: A case study. Project Management Journal, 47(1), 97-112. doi:10.1002/pmj.21558.

Williams, T., Klakegg, O. J., Walker, D. T., Andersen, B., \& Magnussen, O. M. (2012). Identifying and acting on early warning signs in complex projects. Project Management Journal, 43(2), 37-53. doi:10.1002/pmj.21259.

Zhao, X., Hwang, B.G., \& Low, S. P. (2013). Critical success factors for enterprise risk management in Chinese construction companies. Construction Management and Economics, 31(12), 1199-1214. doi:10.1080/01446193.2013.867521.

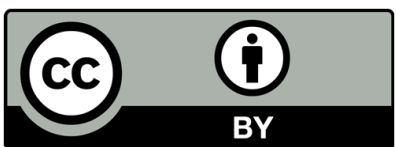

(C) 2022 by the authors; licensee Growing Science, Canada. This is an open access article distributed under the terms and conditions of the Creative Commons Attribution (CC-BY) license (http://creativecommons.org/licenses/by/4.0/). 